\title{
Interfaith Dialogue and Disputation in the Medieval Mediterranean
}

\author{
Brian A. Catlos \\ University of Colorado, Boulder \\ brian.catlos@colorado.edu \\ Alex J. Novikoff \\ Kenyon College \\ novikoffi@kenyon.edu
}

The Mediterranean world in the Middle Ages was a zone of multiple and overlapping identities. In this zone of competing principalities and elites, various groups identified with a particular doctrinal ideology (what we will call "ecumenian"). However, this was also a zone that was characterized by the interpenetration of religious and ethnic communities. Muslims, Jews, and Christians of various denominations and orientations lived amongst each other, rubbing and jostling shoulders socially, competing and collaborating economically, serving in each others' administrations and armies, pleading in each others' courts, passing through each others' homes and beds, and occasionally killing or otherwise inflicting oppression or violence on each other.

Running beneath the formal differences that circumscribed these various real or imagined communities were powerful commonalities. The peoples of the medieval Mediterranean all acknowledged themselves as Abrahamic monotheists who venerated the prophets and patriarchs of the Hebrew tradition. All were heirs to or appropriators of Perso-Hellenistic culture and of Roman and Byzantine institutions, and they shared many of the same legends, myths, folk traditions and magical beliefs. They were joined by common social values and similar ideas regarding gender, social order, beauty, sophistication, and the family. They spoke common languages and shared the sacred languages of their confessional neighbors; they read each others' scripture and appropriated each others' literary traditions. Together this made the Mediterranean a zone of "mutual intelligibility" wherein shared languages, values and conceptual repertoires lubricated cultural communication and made it possible for multi-ethnic, multi-confessional societies to find common ground and 
to function. Simultaneously, the geographic and economic character of the Mediterranean region - a zone of interdependent, highly-developed, specialized, commercialized micro-regions linked by the need to trade, and of societies in which complimentary key economic niches were often dominated by ethnic or religious minority communities-made engagement among discordant communities inevitable. True segregation was therefore nearly impossible, despite the wishes of some religious and secular authorities.

But religious pluralism in the Mediterranean was no Shangri-La of tolerance either. Relationships between members of different communities were predicated on the existence of hierarchies of legitimacy, power, and prestige. Although these societal distinctions may have often been ignored or overridden in practice, they were inescapable conceptually. The rhetoric of the hierarchy and the apparatus of marginalization were present, whether acknowledged or not, in every transaction and encounter between individuals or collectives whose identity was informed by them. The existence of parallel religiously-defined legal regimes that were established within Mediterranean principalities to accommodate the existence of minority communities may have reflected an impressive compromise, but they also served to remind both members of the dominant and the subordinate groups that they were different. The very fact that they were legitimated made them more contentious.

The combination of commonality and difference, of intimacy and estrangement that characterized the Mediterranean world made it one in which individuals were constantly forced to assess, reassess, and defend their own identities and faiths in the face of rival collectives that were threatening precisely because the differences between systems of belief and structures of identity were so subtle. The "narcissism of small differences" ensured that even the most minor differences of doctrine or practice could seem acute. Thus, it was an environment in which individuals were forced to engage continuously in disputation, whether formally or informally, explicitly or implicitly, internally or openly. Disputations took place in the courts of kings, over distance via correspondence or through the crafting of polemic, in the public market place and in the private home, and within the imaginations and internal dialogues of individuals as they questioned and defended their own convictions in the face of continual challenge. And while disputation at times fed discord, and may have encouraged episodes of oppression or popular or official violence against ethnic, religious, or ideological outgroups, it also provided an outlet for anxieties that the threat of assimilation, conversion, or subversion generated in both dominant majorities and subordinate minorities. It helped to define and preserve the social boundaries that were essential to keeping each community in its place and providing multi-confessional societies with stability. 
To put it simply, the exercise of interfaith disputation can be seen as the essence of a heterodox and heterogeneous medieval Mediterranean culture and society where it was not only possible but necessary to continually confront viewpoints and perspectives that challenged and threatened one's own, and in which the security of society and the salvation of believers was seen to lie in preserving the integrity of their communities. In short, the Mediterranean was a world absorbed in dispute and absorbed in disputation.

Disputation lies at the heart of the Medieval Mediterranean world: a world defined on the formal level by difference and tension between competing religious ideologies and doctrines, philosophical interpretations, political regimes, and spiritual orientations. The Mediterranean was of course home to Christians, Muslims and Jews - adherents each to a universalist religious tradition which, whether directly or by implication, denied the validity of any rival faith. Within each tradition there were also important divisions, whether between the Latin, Byzantine Orthodox and members of the various "eastern" Churches, between Rabbinical Jews and Karaites, and between Sunni, Shi'I, and Kharijite Muslims, and the various sub-groups and permutations, whether competing schools of figh, or rival claimants for the imamate, that characterized them. Beyond this, there were cleavages that ran across confessional lines: Aristotelians versus Platonists, mystics versus rationalists, and a myriad of other differences of interpretation or understanding of doctrine and perspective. Finally, although the notion of race was only evolving in this period, there were important distinctions characterized by ethnicity and geographic origin, as can be seen in tensions between Arabs and Berbers, Latins, Greeks and "Orientals," Franks and Muslims, who at times imagined themselves or each other as distinctly generic peoples, and between the members of the various city-states, regions, islands, and towns scattered around the Mediterranean who saw their locale as informing their identity.

Disputation may be characterized as both an informal and a formal method of intellectual controversy. As an informal method, disputation is rooted in the human instinct for argumentation and it has been expressed over time in a wide body of debate literature, both poetic and prose and both historical and fictive. As a formal method, disputation may be viewed as a series of rules of engagement for debating and challenging opposing claims. While these rules perhaps developed most formally in the medieval West, where scholastic disputation came to define one of the core features of the university curriculum 
(and in a sense still does), formal procedures for intellectual debate also existed within the traditions of Judaism and Islam. This is not surprising given that all three religious cultures owe a great intellectual inheritance to the Greco-Roman world that preceded them. Indeed, both the worlds of classical antiquity and the early Judeo-Christian societies were ones that cultivated the art of debate. A brief review of these developments will help to situate the contributions that follow.

The classical Greek inspiration for intellectual debate is well known. Plato showed very effectively that the form of a philosophical dialogue could express what a mere monologue could not. For Plato, dialectic (the art of discussion) was part of the practice of dialogue, which for him consisted in an examination of a thesis by means of orderly questions and answers. Socrates applied a sort of conversational dialectic to his daily interrogations with his fellow Athenians, and this was what Plato attempted to capture and represent in his written dialogues. Aristotle, on the other hand, considered the questionand-answer approach a purely formal method that cannot lead to any scientific result. He therefore distinguished between dialectical and demonstrative premises and also between pedagogical and dialectical arguments. In his Topics and in his Rhetoric, Aristotle provided the schemes of argumentation that enable one to find the premise necessary to arrive at a conclusion for any problem. Book viII of the Topics, in particular, provides the rules disputational debate in which the interrogator and the respondent argue out the issues in a sort of intellectual duel. Aristotle and his followers used this form of dialectical engagement extensively, not only as an exercise and teaching method, but also as an essential part of philosophy. This became one of the main vehicles for all forms of philosophical inquiry and intellectual engagement. It is found throughout the classical and late antique world, and ranging across a variety of disciplines including Roman law and early Christian apologetics. The constant and public search for certainty - legal, political, scriptural, or othergenerated its own form of resistance, and it is out of such resistance that one finds an abundance of medieval writings that involve inter-communal and intra-communal debates.

The essays that follow all attest to the common and contested intellectual space occupied by Christians, Muslims, and Jews in the medieval Mediterranean. The period covered by these essays is the twelfth century to the sixteenth century, a period of increasing mobility and inter-confessional encounters. In "Peter the Venerable on the Talmud, the Jews, and Islam," Irven Resnick looks at the correlation between Jews and Muslims as it is expressed in the polemical writings of the famous twelfth-century abbot of Cluny. Peter the Venerable is exceptional in the amount of energy he devoted to refuting 
the truth claims of Jews and Muslims; he commissioned the first translation of the Qur'ann and in his anti-Jewish work he was the first to name the Talmud as such. Rather than view the attack on Jews and the attack on Muslims as separate enterprises, Resnick shows how Peter viewed the Talmud simultaneously as a source of error for both Jews and Muslims.

The next three essays are concerned with Islamic responses to interfaith debate, offering valuable comparative perspectives rarely found elsewhere. In "The Disciples as Companions: Ibn Taymiyya's and Ibn al-Qayyim's Evaluation of the Transmission of the Bible," Younus Mirza, shows how two fourteenthcentury 'ulama' deployed a methodology of authenticating hadith transmission in order to cast doubt on the accuracy of the Bible. Demonstrating the corrupted nature of Christian Scripture became a strategy for vindicating the Qur'ān and the truth of Islam. Mónica Colominas Aparicio's "Predestination and Free Will in Mudejar Polemics" examines a unique early-fifteenth-century manuscript, "The Book Called Disputation with the Jews and the Christians" in which the defence of specific religious doctrines were deployed by the vulnerable subject Muslim community in the Iberian Peninsula, a symptom not only of the distance between the three religious communities, but also of their integration and proximity. In "Theology from the Margins: Sīdī Riḍwān al-Januwi and his Community of Outsiders," Manuela Ceballos surveys the life and career of Sìdī Riḍwān, a sixteenth-century Moroccan sufi who was the son of a Genoese convert and a Jewish woman from al-Andalus and shows how the universalist ideals of Islam were complicated in the way contemporaries viewed him by ethnic modes of identity at a time of heightened political and religious tensions in the Maghrib and western Mediterranean.

The next two essays highlight the importance of intra-confessional dispute. Jeff Brubaker examines the language of disputation between Latins and Greeks in the Byzantine Empire. Focusing on the period of the Latin occupation of Constantinople that resulted from the Fourth Crusade (1204), and more specifically on the so-called disputatio of 1234 , Brubaker is able to reconstruct the vocabulary and content of an ecclesiastical dialogue between Latin friars and their Byzantine counterparts as they discussed the theological issues that divided Catholicism and Orthodoxy. The theological and political circumstances of this particular event, Brubaker concludes, challenge us to rethink the format and boundaries of intra-Christian dialogue. In "Sites of Controversy: Jews Debating Philosophy Between Barcelona and Montpellier in the Fourteenth Century," Tamar Marvin takes us into the world of intra-Jewish disputes over the interpretation of Maimonides. Focusing on an early fourteenth-century compilation of letters and sermons, Marvin dissects the various stances towards rationalist philosophy that played out in Occitania in the 
century between the death of Maimonides (1204) and the French expulsion of the Jews from France (1306). Marvin especially emphasizes the role of letters as physical objects and public communications that were shaped by their transmitters and protected by Jewish law. She notes the power of ideas and the power of debate in mobilizing leaders to respond to an intellectual issue that impacted the entire Jewish community and not just the scholarly elites who mediated the discussion.

The final two essays return to Christian Europe, looking at Christian interactions with Muslims and Jews in literary and performative representations. Kaarlo Havu takes up the Humanist scholar Juan Luis Vives's conception of Islam as reflected in his dialogue De veritate fidei Christianae, posthumously published in 1542. Like so many of the medieval polemics that preceded it, the work is framed as a (fictional) dialogue between a Christian and Muslim, the purpose here being to systematically uncover the flaws in Islam and the unethical nature of Muhammad. This, in itself, is not new. However, by placing Vives within the Erasmian paradigm of asymmetrical dialogue that tolerates error in order to overcome it, Havu argues that the rhetorical strategy adopted by Vives has more political resonance than previously assumed. He asserts that the dialogue with the Muslim paints a picture of Muhammad that readers familiar with Erasmian commonplaces would have recognized as a close reproduction of the Erasmian tyrant. Thus, Muhammad in the dialogue is not merely a sketch drawn from existing commonplaces. Rather, the figure of the Muslim prophet is intentionally turned into the central theme and argumentative nucleus of the whole piece. In "Drama as Disputation in Mantua," Erith Jaffe-Berg's argues that theatre functioned as a forum for disputation in Mantua supplanting the need for a formal tradition of disputation. Theatre provided a context for the exchange in ideas about social functioning within each community, and it enabled Jewish community members to air ideas about the value of Jewish ideals in relation to Christian ideals. As soon as the Jews ceased producing theatre for their own community and for the Christian community, disputation began. In one sense, it appears as if the absence of theatre as a public forum for exchange made it necessary to have recourse to disputations.

Collectively, these essays underscore the shared and competing identities fostered by interfaith disputation, which may in turn be characterized as a key mode of interreligious communication in the medieval Mediterranean. The texts discussed by the contributing authors suggest that those engaged in disputational writing were both participants in, and products of, a multifaceted sphere of inter-communal activity where members of conflicting groups challenged their adversaries and constructed their own identities through deliberate strategies of dialectical engagement. Like the geographic zones that they 
inhabited, these disputational cultures were both overlapping and distinct, continually shifting and evolving in order to meet the newest challenges and address the most immediate concerns. It is our hope and conviction, as editors, that this collection of excellent and diverse essays will serve not only to illuminate the particular historical episodes that they focus on but will contribute to our understanding of the pre-modern Mediterranean and to the phenomenon of disputation in this period. 